\title{
Bonding, Bridging and Linking Relationships of the CSR Target Communities of PT Pertamina Refinery Unit II Sungai Pakning
}

\author{
MIFTAH FARIDL WIDHAGDHA \\ HERMIN INDAH WAHYUNI \\ MUHAMMAD SULHAN \\ Gadjah Mada University, Indonesia
}

\begin{abstract}
PT Pertamina (Persero) Sungai Pakning Refinery Unit II as one of Indonesia's state-owned oil and gas companies has contributed to the empowerment of communities around its operational areas through the Corporate Social Responsibility (CSR) scheme. In carrying out CSR programs, the company pays attention to the social relations of the target communities. This study focuses on analyzing the forms of social relations of the CSR target communities and their impacts on the implementation of CSR programs of PT Pertamina (Persero) Refinery Unit II Sungai Pakning. Social relations in this study are defined into three forms of relations, namely bonding, bridging and linking, each of which has different impacts on the social conditions of the beneficiary communities. This research is based on qualitative approach, conducted in three target communities in different areas within Bengkalis Regency, Riau Province, namely Sungai Pakning Village, Sungai Selari Village, and Pangkalan Jambi Village, during the period of 2017-2018. The data were collected through in-depth interviews, observations, and documentations. The study finds various forms of social relations. Bonding relations show that intra-group bonds are important to maintain group cohesiveness. Bridging relations show that ties between groups need to be developed in order to connect each others and work together. While the linking relationships show that there is a good impact for groups that have closer relationships with the higher power institutions. These results indicate that the forms of social relations have important impacts on the implementation of CSR programs and need to be maintained through participatory communication activities in order to create sustainable social relations. This study also finds that good social relations will be strong support to raise community awareness and participation in practicing sustainable environmental management.
\end{abstract}

Keywords: Corporate social responsibility, community empowerment, bonding relationship, bridging relationship, linking relationship.

\section{INTRODUCTION}

Corporate Social Responsibility, hereinafter referred to as CSR, has increasingly become a serious conversation in the global corporate forums in recent years. In Indonesia, conversations about CSR are not only dominated by global corporations, but have also discussed by the state-owned corporations and national private companies who are starting to seriously work on their CSR programs to support the formation of positive corporate images. One of the levers is increasing concern to the environmental issues such as climate change which has encouraged the creation of many regulations, agreements, and conventions on the importance of corporation roles in safeguarding environmental sustainability. The efforts to pay more attention to the environmental aspects are highlighted by the reality that the existence of the environment can never be separated from the existence of the surrounding local communities. Thus, the discourse about environmental sustainability and local communities continue to be explored in the last few decades. 
PT Pertamina (Persero) is one of the Indonesian state-owned corporations that implement CSR as a form of social and environmental responsibility. This study seeks to explore how social relations are formed in the local communities guided by CSR programs of PT Pertamina (Persero), taking a case study in one of its operational areas, namely PT Pertamina Refinery Unit II, Sungai Pakning Refinery, located in the Sungai Pakning Village, Bukit Batu Sub-district, Bengkalis Regency, Riau Province, Indonesia. This study will be an important contribution to the theoretical discussion about the relations of social aspects with CSR programs management.

\section{LITERATURE REVIEW}

Even though the discourse on the local communities involvement in CSR practices has been echoed in various discussions, both at national and international levels, in the reality local communities are often still left behind in the CSR implementations, especially in the environmental fields (Cantrill, 2015). Corporations often ignore social relations and mechanisms exist in the community, resulting in the fail of community-based environmental conservations (Widhagdha, Wahyuni \& Sulhan, 2019).

Another important aspect increasing the paradox of CSR, especially among local communities, is the distrust to the CSR programs since corporations include too many corporate interests, such as marketing and corporate images, not focus on solving the problems faced by the community. Edelman (2009) with Jahdi and Acikdilli (2009) have reported that stakeholders, especially the community, lost their trust in the social responsibility efforts carried out by corporations because of many interests included in the CSR activities, such as marketing and public relations spin. One possible way to regain public trust from the local communities is re-establishing relationships and trust between corporations and the community, as well as being more involved in the social relations that occur within the locals in order to get the comprehensive picture of their social conditions. This holistic picture may be used as a basis in designing CSR programs for the locals in order to make sustainable social impacts and regain their trust.

Understanding social aspects as one of the important bridges for the CSR implementation has been emphasized in many studies. The implementation of CSR is considered to have significant social impacts in the relations arise between corporation and community (Cortado \& Chalmeta, 2016). Besides, the implementation of CSR is also considered capable of reducing various local conflicts that may occur between corporations and communities (McCharty et al., 2017). Social relations are the type of social capital (Goodwin, 2003). Coleman (1988) and Grootaert et al. (2004) have explained social capital as the manifestation of social relations, emphasizing the access that individuals have in the existing social order. Previous studies have introduced three types of social relations namely bonding, bridging and linking (Putnam, 1993; Woolcock, 2001). Bonding means the social relations arising among homogeneous communities horizontally, bridging explains the social relations that arise in heterogeneous communities horizontally, while linking refers to the vertical social relations between communities with another higher community.

This study is interested in reviewing these three types of social relations in the social dynamics of the partner communities of the CSR programs of PT Pertamina (Persero) Refinery Unit II Sungai Pakning. This research expects to provide comprehensive descriptions of the forms and characteristics of social bonding, bridging and linking 
relationships in the partner communities being studied and their impacts on the CSR implementations of PT Pertamina (Persero) Refinery Unit II Sungai Pakning.

\section{METHOD}

This paper is based on a qualitative study with the interpretive approach as introduced by Neuman (2014). The interpretive effort was expected to be able to understand meanings in various social actions through a system of meanings created and maintained by the community. The location of the study was the CSR program areas of PT. Pertamina Refinery Unit II Sungai Pakning. This company is one of the oil and gas companies in Indonesia with a type of crude oil processing activities. It has CSR areas covering Sungai Pakning Village and another four villages, namely Sejangat Village, Pakning Asal Village, Sungai Village Selari, and Batang Duku Village. Each village becomes the place for implementing different CSR programs based on their environmental conditions, economic levels, and social dynamics. In this context, more information is needed to know social capitals of each village and their relations to the CSR implementation.

The selection of informants in this study was purposive based, especially individuals who are expected to have relationship or aware with the research problems. The informants were members of the partner groups of CSR programs of PT Pertamina Sungai Pakning Refinery, consisting of Tunas Makmur Farmer Group, Fire Care Community of Sungai Selari Village, and Harapan Bersama Fisherman Group. While other informants were CSR staff of PT. Pertamina Refinery Unit II Sungai Pakning and head of Sungai Pakning village. Overall there were eight informants who took part in this study.

The data have been collected through in-depth interviews, participatory observations, and documentations. These three techniques of data collection allow the study to conduct data triangulation in order to ensure the validity of the data. In the data analysis level, this study has applied three steps of analysis, namely reducing the data, displaying the data, and drawing conclusions and verifications (Miles \& Huberman, 1994).

\section{RESULTS AND DISCUSSION}

This chapter describes the bonding, bridging and linking relations that exist within the CSRassisted communities of PT Pertamina (Persero) Sungai Pakning Refinery Unit II. It also discusses the roles of these social relations to the social dynamics of the groups, to the implementation of CSR programs, and to the issue of environmental sustainability as well.

\section{Bonding Relations in the Communities}

Bonding relations exist in the community can be divided into two broad categories, namely structural and cognitive form (Woolcock \& Narayan, 2000). Structural bonding is form of relationships based on rules that regulate the role of its members in achieving common goals. While cognitive bonding is relationships based on common values and norms, beliefs and social attitudes to achieve common goals. Cognitive bonding relations indicate the existence of communitarian values that prioritize the similarity of values and ideology in the group. In the communitarian group, bonding relationships show the existence of close social cohesion, emphasizing harmonization between members in the group. 
Table 1: Forms and characteristics of bonding relations in partner communities of CSR programs of PT Pertamina RU II Sungai Pakning

\begin{tabular}{|c|c|c|c|}
\hline $\begin{array}{c}\text { Characteristics of } \\
\text { Bonding } \\
\text { Relationship }\end{array}$ & $\begin{array}{l}\text { Tunas Makmur } \\
\text { Farmer Group }\end{array}$ & $\begin{array}{l}\text { MPA Sungai Selari } \\
\text { Village }\end{array}$ & $\begin{array}{l}\text { Harapan Bersama } \\
\text { Fisherman Group }\end{array}$ \\
\hline $\begin{array}{l}\text { Category of } \\
\text { relations }\end{array}$ & Mixed & Structural & Cognitive \\
\hline Institutional forms & Formal & Formal & Formal \\
\hline Similarity forms & Kinship/Family & Territory & Territory \& profession \\
\hline $\begin{array}{l}\text { Form of decision } \\
\text { making forum }\end{array}$ & $\begin{array}{l}\text { Deliberation \& } \\
\text { meeting }\end{array}$ & $\begin{array}{l}\text { Village head meeting \& } \\
\text { instruction }\end{array}$ & Deliberation \& meeting \\
\hline Form of regulation & $\begin{array}{l}\text { Articles of the } \\
\text { group, consensus }\end{array}$ & $\begin{array}{l}\text { Rules of the village } \\
\text { head, consensus }\end{array}$ & Consensus, customary \\
\hline $\begin{array}{l}\text { Form of bonding } \\
\text { strengthening }\end{array}$ & Royong & Patrol & Turun kapal \\
\hline Key figure & Group leader & $\begin{array}{l}\text { Village head, group } \\
\text { leader }\end{array}$ & $\begin{array}{l}\text { Group leader, village } \\
\text { leader, religion leader }\end{array}$ \\
\hline
\end{tabular}

\section{a. Bonding at Tunas Makmur Farmer Group}

In Tunas Makmur Farmer Group, the forms and characteristics of bonding relations can be observed through family closeness found in almost all group members. All of the 31 group members are extended families who have lived in the area for a long time. The majority of them are descendants of Javanese migrant who migrated to Sumatra during the 1950-1960 periods. Since the formation of the group to the date, the increasing number of members are more common in close relatives or residents who live close to the group location. Because of its kinship-based characteristic, the internal coordination becomes relatively easier because the close gaps between the houses and a quite strong informal communication that has already established. This characteristic shows the existence of a strong communitarian tradition referring to what Putnam (1993) said that this tradition prioritizes aspects of kinship and common values or norms in society. This communitarian tradition is also reflected in the existence of local wisdom, namely gotong royong in the Tunas Makmur Farmer community. This local wisdom can be seen from the willingness to voluntarily help other members who are grieving, or conversely holding celebrations. A member of this group described how they are strongly bound to one another:

\footnotetext{
"Yes, we basically are all familiar, we are close to each other, we will help what we can help the others. For example, there is member who is having misfortune, then everyone will help. Another example, someone who build a house, so we will work together. Anyway, we help as much as we can, that is why we are close to each other until now" (S, interview, 21 August 2018).
}

But on the other hand, because the majority of group members are relatives or extended families, they are being more selective in accepting new members outside their groups. It confirms the tendency of bonding relation characteristics that give rise to the group protective attitudes.

This attitude is a form to protect core values of the group from the external influences, such as from members who do not come from the same background, as well as to minimize conflicts that arise due to background differences. It could be regarded as a form of maintaining cohesiveness and solidity in the group. Considering also the group 
location which is quite far from the city centre, the choice to maintain social ties and trust is one strategy to maintain the existing bonding relationships.

\title{
b. Bonding at Fire Care Community
}

The Fire Care Community of Sungai Selari Village (MPA) is a group formed by the head of village in order to respond to the forest fires that frequently occur in the region. The formation of its members is also based on the open recruitment within the community members who are willing to conduct routine surveillance and patrol in the forest. Thus, the character of the group is more structural, because of which they emphasize on the regulations made by the village head as the basic rules that must be obeyed by all members. The village head has important roles in maintaining group solidity. The group will coordinate and consult to the village head when they are facing certain problems that could not be solved by themselves. The closeness between group members is also based on the similarity of membership and settlement area, not because of their homogeneous backgrounds. The group members consist of different ethnic background, such as Malay, Java and Batak. This characteristic actually shows the weakness of the bonding relationships since it is not built on intimate relationships.

Weak bonding relations between members also have impact to the limited collective voluntary action as a main characteristic of bonding relations. Each member tends not to show any concerns for the problems experienced by other members, but they would rather ask the head of village to decide and solve the problems. The aspects that still maintain the bonding relations in the Fire Care Group of Sungai Selari Village are the presence in the routine meeting and community orientation forum which can still be maintained since the group is formed for specific purposes, namely patrols and blackouts forest and land fires. Solidarity in this group is manifested in mutual respect between members and focus on the group purpose as fire fighting patrol officers. This need-base bonding relation has been expressed by a member of this group:

\begin{abstract}
"What is clear is that we respect each other, because we are here voluntarily, not paid. So, the members must have their own work, we all know it. What is important if there is a need, MPA is ready, that is all" ( $Z$, interview, 24 August 2018).
\end{abstract}

\section{c. Bonding at Harapan Bersama Fisherman Group}

Harapan Bersama Fisherman Group is a group of fisherman in the village of Pangkalan Jambi. Geographically, this group occupies coastal areas and has similar activities with general fisherman's villages, such as sailing, catching fish, and another aquaculture activity. This group was formed because of the similarity of occupation as fisherman, the closeness of the settlement that is Bengkalis strait coast, as well as the similarity of Malay customs in their communities. The area closeness as one of bonding relation characteristics confirms some previous studies that link the strong regional influence with the social relations that arise (Healy, Haynes \& Hampshire, 2007). All of the 21 members of the group are residents of Pangkalan Jambi Village who work as fisherman, besides they are all Malay tribes. It shows that similarity or homogeneity encourages the formation of strong bonding relationships between group members. The background of tribal similarity found in the Harapan Bersama Fisheries Group also shows the existence of communitarian traditions 
(Putnam, 1993). The presence of local wisdom is reflected in the turun kapal ritual as a form of gratitude to the God Almighty as well as the realization of solidarity among fisherman. A member of this group has emphasized that their ethnic and occupational similarities are the basis of their strong bonding relations:

"We are all Malays, we all go to sea to the Bengkalis Strait, so we are all fishermen here, in Pangkalan Jambi. There are two groups of fishermen, one is our group and recently there was an additional group for our mothers" (A, interview, 22 August 2018).

Although not based on kinship or family relationships, the quality of strong bonding relations can also be found in groups with similar occupational and cultural backgrounds as found in this group. The relationship tends to be cognitive forms by looking at the role of strong social leaders, such as religion leader and another community leader. These relationship patterns are manifestation of social norms which exist to reinforce the bonding relations in fishing communities. However, the emphasize to the background similarities will cause the tendency to protect group bonding and to reject new individuals (out groups) to become members due to the reasons of group cohesiveness. This attitude tends to be strong in groups that have high similar backgrounds, such as the similarity of kinship, territory, ethnicity, and others.

\section{Bridging Relations Between Communities}

Bridging relations are indication of the existence of social connections in diverse (heterogeneous) groups that encourage the creation of social inclusiveness from population diversity and identity. Bridging relations arise due to limited resources from the internal condition of the group, because of that they need to work with other groups to meet their needs. It indicates that bridging relations are driven by cosmopolitanism, where groups are encouraged to practice new knowledge in order to complete the limitations they have. In bridging relations, the emphasis is on the equal relationships between one group or individual with another group or individual. Thus, bridging relations are social networks connecting between groups to at least exchange information and work together.

\section{a. Bridging between Tunas Makmur Farmer Group and Fire Care Community}

Bridging relationships between Tunas Makmur Farmer Group and Fire Care Community Group are based on symbiotic mutualism relationships, in which each group needs certain helps from the other groups. As mentioned beforehand, the Tunas Makmur Farmer Group is a group engaged in agriculture and forestry activities by utilizing ex-forest fires in the Sungai Pakning area to be used as pineapple farms, while the Fire Group is a group formed by the local village government to conduct patrols and fire preventions in the early stages. Each has an interest in preventing land fires because it will harm both parties. Thus, keeping the land and forest from burning will be a reciprocal benefit for both parties. However, this relationship is created only because of the need of each party to benefit from the existence and role of other parties. It shows that each group actually does not have strong ties that are able to keep the relationship going in a long time if each group has no longer benefited. A member of Fire Care Community explained this mutual bridging relation: 


\begin{abstract}
"Yes, we and the pineapple group help each other. They are guarding their land, it also helps us to protect the land from fire, so our patrols are getting easier, we have no longer to bother patrolling deep there in the forest" $(Z$, interview, 24 August 2018).
\end{abstract}

The relations between the two groups are mostly due to the similarity of activities in protecting the land from potential fires. Thus, if fire mitigation has become a new habit of the whole community members and the Fire Care Group does not have to do routine patrols anymore, then what have been established between these two groups will also be weaken.

\title{
b. Bridging between Tunas Makmur Farmer Group and Harapan Bersama Fisherman Group
}

Bridging relations between Tunas Makmur Farmer Group and Harapan Bersama Fisherman Group were formed through discussion and joint learning activities related to the group business development. As a group that was first developed by Pertamina, Tunas Makmur Farmer Group often acts as a coach for other groups in terms of business development and institutional strengthening, including for Harapan Bersama Fisherman Group. This knowledge sharing activity was carried out because of the sense of togetherness that was established among partner groups of Pertamina CSR programs, so that each group felt equal in their positions. A member of Harapan Bersama Group expressed this coaching and learning relations:

\footnotetext{
"Regarding our relationships with other groups, we admit that we also learned. To whom? To a more advanced group. So, we were introduced by Pertamina to the Pineapple Group in Java Village, we learned there. It turned out they have been able to proceed pineapples into various foods, well from there we want to learn, who knows it can be our activity here too" ( $A$, interview, 22 August 2018).
}

However, the relationships that occur between groups more indicate the transactional relationships based on the need of resources that are not owned by the group but are owned by another groups. It is somehow different with the attitude of the group in welcoming new members from the outside communities, which the groups are more protective or providing blocks for outsider to be a group member. But, in case of inter-group relations, groups are more open themselves to connect with another groups to the extent that the relationship can provide benefits to the group.

The bridging relationship formed between the two groups indicates that there are limited resources in one group so that it requires the group to connect with other groups to be able to fulfil these resources. It shows a strong cosmopolitan attitude from the Harapan Bersama Fisherman Group because they want to learn from other groups, especially knowledge about ecotourism management and institutional strengthening. This new knowledge is then obtained from the bridging relationships with the Tunas Makmur Farmer Group that has previously managed ecotourism and strengthened their institutional capacities. 


\section{c. Bridging Between Harapan Bersama Fisheries Group and Fire Care Community}

Bridging relations occurred between Harapan Bersama Fisherman Group and Sungai Selari Fire Care Group were not found much during the study. From the interviews with both parties, the relationship that occurred was limited to the relationship facilitated by Pertamina as a patron in the community empowerment activities for the two groups. The limited relations can be seen from the absence of shared interests between the two groups.

In term of region, these two groups also do not directly interfere, thus making the possibility of relations arising due to the area proximity is also limited. The absence of bridging relationship between Harapan Bersama Fisheries Group and the Sungai Selari Fire Care Group is understandable because indeed these two groups do not share certain resources to be able to solve common problems.

In summary, the bridging relations between each of the partner groups are as follows:

Table 2: Characteristics of bridging relationships between partner communities of CSR program of PT Pertamina (Persero) RU II Sungai Pakning

\begin{tabular}{lccc}
\hline $\begin{array}{l}\text { Characteristics of Bridging } \\
\text { Relationships }\end{array}$ & $\begin{array}{c}\text { Tunas Makmur } \\
\text { Farmer Group }\end{array}$ & Fire Care Group & $\begin{array}{c}\text { Harapan Bersama } \\
\text { Fisherman Group }\end{array}$ \\
\hline Tunas Makmur Farmer Group & - & $\begin{array}{c}\text { Coordination, } \\
\text { patrol, fulfilment } \\
\text { of labour }\end{array}$ & Training \\
Fire Care Group & $\begin{array}{c}\text { Coordination, } \\
\text { patrol, fulfilment } \\
\text { of labour } \\
\text { Training }\end{array}$ & - & None \\
$\begin{array}{l}\text { Harapan Bersama Fisherman } \\
\text { Group }\end{array}$ & None & \\
\hline
\end{tabular}

\section{Linking Relations of Partner Communities}

Linking is social relationships formed between individuals or groups with the higher individuals or groups having more economic, social or political power, such as political or financial groups, in order to be able to achieve common goals (Woolcock \& Narayan 2000). The characteristics of linking relationships are actually similar to bridging relations, both of them connect one group with another group to be able to fulfil the needed resources in order to achieve common goals. However, a significant difference between these two relations is that the bridging relationship is an equal relation (horizontal) between the two groups, while the linking relationship is an unequal relationship between stronger and weaker parties. Linking relationship emphasizes participatory attitudes from the involved parties to solve certain problems (Grootaert et al., 2004).

Linking relationships will emerge interconnections between various parties that allow resources sharing to achieve development goals. However, the interconnections created from linking relations are highly dependent on the pre-existing shared common values between the groups involved. The agreement of these values, for example, is indicated by the willingness to become a fostered community of a company with the consequence that the group must follow programs carried out by the company. Such an agreement is very strong in its role in establishing linking relations. In this study, the elite group considered to have greater strength is PT Pertamina (Persero) RU II Sungai Pakning who has CSR programs to foster Tunas Makmur Farmer Group, Fire Care Group, and Harapan Bersama Fisherman Group. Although, it should be also taken into account the 
existence and roles of the regional government, including village, sub-district, and district government, to give guidance and assistances to the local communities.

Finally, this study proposes a model of bonding, bridging and linking relationships of the partner groups of CSR programs of PT Pertamina (Persero) RU II Sungai Pakning, as follows:

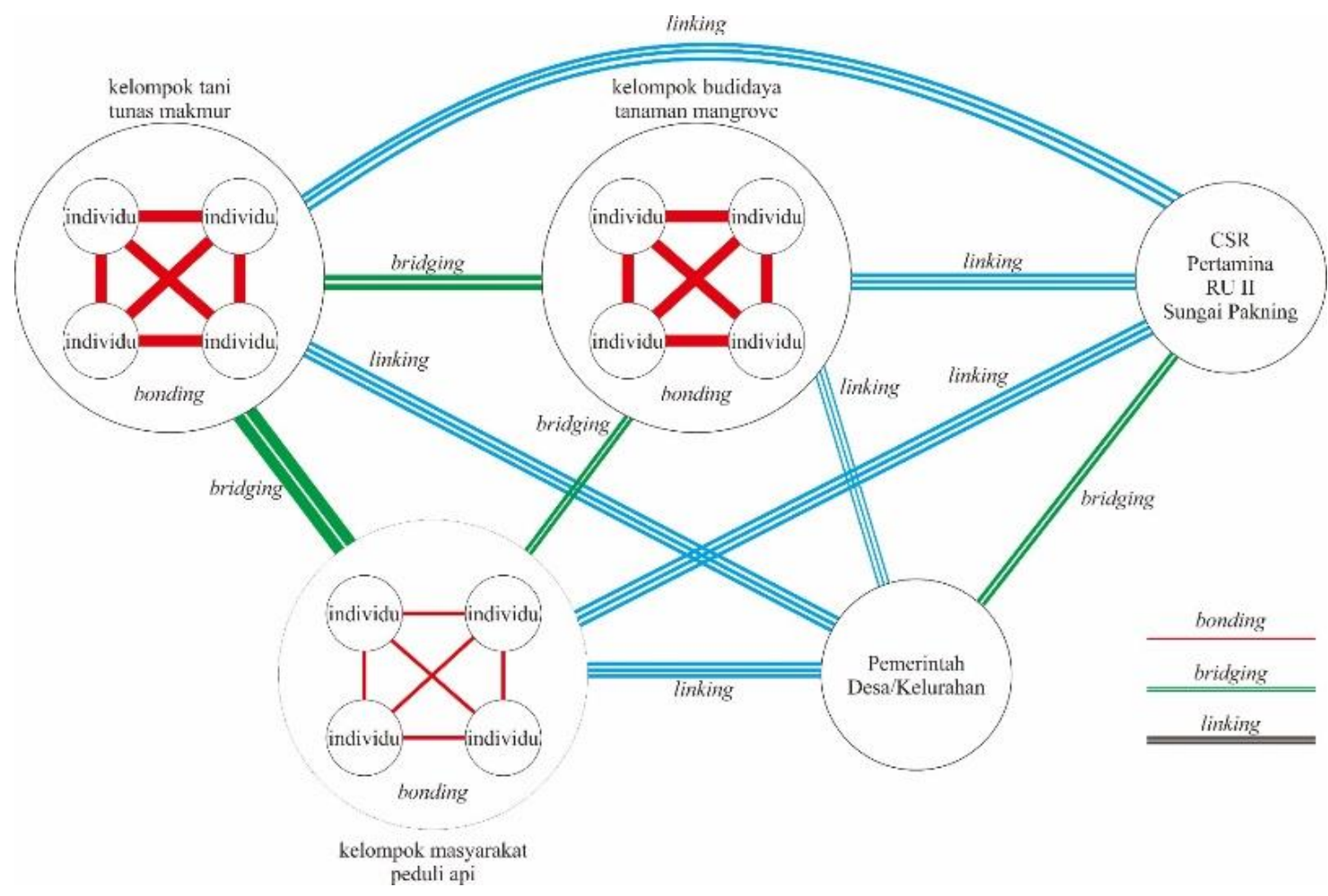

Figure 1: Bonding, bridging, and linking relations model of partner groups of PT Pertamina (Persero) Refinery Unit II CSR programs in 2017-2018. The thicker line shows the stronger relations, while the thinner shows the weaker relations.

The Impact of Bonding, Bridging, and Linking Relationships on the CSR Programs Implementation

This study finds that each relations have positive and negative impacts as well for the implementation of CSR programs. In general, bonding relations show strong impact on social cohesion in the internal level of groups. The similarity of background, both the similarity of region, occupation and ethnicity, have strong impacts in shaping the group unity and sense of belonging of the group members. A very strong bonding relationship was observed in the activities carried out by Tunas Makmur Farmer Group, which was formed by similarities of territory, line of descent, and occupation in managing pineapple farming. This type of relationship also emerged in the Harapan Bersama Fisherman Group which was motivated by the similar tribal, territorial and occupational spirits. In Fire Care Community, although bonding relations did not have strong impact on the presence of tough social cohesion among members, but at least based on the occupation similarity, it had been able to maintain group solidarity for quite a long time. 
The existence of strong bonding relations in each group can help program managers of CSR to coordinate, consolidate and implement CSR programs that have been designed. The strength of bonding relations is also evident in the involvement and active participations shown by all group members in the CSR program implementations. This involvement and active participations are possible due to the equitable access for every group member to get involved in the CSR program implementations. Bonding relations also appear to have strong impact on the collective actions. The established joint works can be seen as a sign of the cohesiveness and volunteerism among group members to help other members, or to take care of public facilities in their area. However, as mentioned beforehand, the strong characteristic of bonding relations in the two groups, namely Tunas Makmur Farmer Group and Harapan Bersama Fisherman Group, tend to protect their social cohesiveness and reject the presence of new members, which are considered to hamper the institutional development of the group as expected by CSR managers. In fact, the growth in the number of members, the rise of institutional development, and the exchange of information between groups are the key successful indicators of the CSR programs implementations that aim to empower the community.

As mentioned beforehand, this study finds different characteristics of bridging relations in each group. In Tunas Makmur Farmer Group, bridging relations are used to strengthen the agricultural management as their main activities. This relationship appeared in line with the development of the activities scale managed by Tunas Makmur Farmer Group. In Sungai Selari Fire Care MPA Group, bridging relations emerged as result of the implementation of Pertamina's CSR programs which has carried out empowerment programs and formed an inter-MPA forum in the district. Bridging relations were then able to be a driver of the formation of social inclusion among MPA members from nearby villages to help each other in the context of fire patrol activities. In implementing CSR, bridging relations between MPA groups in each village facilitate the management of CSR programs, since they are easier in terms of coordination and guidance. Manager of CSR programs have no longer to deal with each MPA groups. The communications are centralized in a common forum, namely the MPA Communication Forum (FORKOMPA) which has increased the program communication and coordination into much more effective.

In Harapan Bersama Fisheries Group, bridging relations actually emerged as the result of the CSR programs carried out by the company. The bridging relationships that had been established previously between groups of fisherman in the region had a positive impact on the establishment of Harapan Bersama Fisherman Group. Thanks to this relationship, Harapan Bersama Fisherman Group can be recognized by Pertamina and become a partner in implementing CSR programs in the Jambi Pangkalan Village area. To sum up, the three groups show fundamental differences regarding the characteristics of bridging relationships, as well as the different impacts they have on the implementation of CSR programs.

While linking relations play very big role in the implementation of CSR because basically through this relationship the link between each group and Pertamina as the patron and supervisor of the CSR programs can be well established. Through this linking relationship, the group received additional knowledge, access to marketing, as well as capital and institutional strengthening. However, the linking relations in each group also have several different characteristics. In MPA Sungai Selari Group, the linking relationship initiated by Pertamina is a cause that make them able to connect and build bridging 
relations between MPA groups. Through this linking relationship, the company can provide guidance and assistance to the MPA group both from Sungai Selari Village, as well as from another surrounding village.

In Harapan Bersama Fisherman Group, the linking relationship emerged as a result of the bridging relations that already exist among the fishing groups in the region. In implementing CSR, the emergence of linking as a result of bridging relations is considered as positive to strengthen institutional capacities and increase the number of members. Through linking relationships that grow naturally, the groups can express their opinions regarding the program development based on their perspectives. The linking characteristics allow the formation of a closer relationship between the company and the partners. Thus, Pertamina can change and move forward their programs to the better approaches based on the group suggestions.

The Impact of Bonding, Bridging, and Linking Relationships on the Environmental Sustainability

As one of the CSR programs that should have impacts on environmental sustainability, the existence of good bonding, bridging and linking relations can be seen as an effort to increase community participation in maintaining and preserving sustainable environmental management. The success of company in managing its social relations with the communities also gives the hope that these environmentally oriented CSR programs can be continued independently by the people who receive benefits from the program.

For example, the implementation of fire prevention programs that have been successfully carried out by Fire Care Community and Tunas Makmur Farmer Group are able to prevent fires and proceed the burned land into productive pineapple farming areas. As a result, the community can enjoy economic and ecological benefits simultaneously. This can certainly occur because of the creation of good social relationships between Fire Care Community and Tunas Makmur Farmer Group who are sharing roles each other so that each can carry out their duties properly. In addition, in Harapan Bersama Fisheries Group, their limited knowledge about ecotourism management can be overcome by discussion and learning activities conducted with Tunas Makmur Farmer Group. This activity is also encouraged because the social relations between the two groups are good enough to enable information and knowledge exchanges.

Moreover, these programs have not only succeeded in educating public about the importance of environmental protections, but also utilizing the environment resources with sustainable management. This success is of course built from good social relations, in which the company is not only seen as a donor but as an equal partner in implementing environmental management programs through CSR activities. Thus, sustainable environmental management is not a mere corporate responsibility, but should be a shared responsibility carried out through collaborative woks, which could be realized through the establishment of good social relations between parties.

\section{CONCLUSION}

This research is an effort to move forward the general trend of research on CSR which previously focused on the level of policy and macro level, to be more focused on micro aspects, especially on the social relations that play important roles in the success of CSR program implementations. 
This study has found various forms of social relations, including diversity of bonding, bridging and linking relations in the three communities that have been studied. Bonding relations show strong impacts on social cohesion in the internal level of groups. The very strong bonding relations have found in two groups, namely Tunas Makmur Farmer Group and Harapan Bersama Fisherman Group. Their strong bonding relations are based on their internal similarities, both similarity of kinship, occupation, culture and ethnicity, and geographical areas. It has impacted in forming group cohesion and sense of belonging within group members. While, a weaker bonding relationship has found in the Fire Care Community, which was structurally initiated by the village government and mostly based on the common interest, namely preventing forest fires.

This study has also found that bonding, bridging and linking relations have different impacts in managing social dynamics in the community. The existence of bonding, bridging and linking relations within the target communities do have diverse impacts on the efforts to manage the CSR activities. Bonding relations need to be continuously maintained in order to keep group cohesiveness. Whereas bridging relations need to be developed in order to connect with another groups, work together, as well as create more equitable social inclusion. While linking relationships show good impacts for groups that have closer relationships with the higher power institutions. It raises an idea that resources from stronger social institutions can be shared to build community welfare through the establishment of open and transparent relations between the communities and the higher social institutions in the region.

In general, at the micro level, social relations in the partner communities can be so diverse and they have different impacts on the implementation of CSR programs. Thus, policy makers or CSR managers should seriously take into account these diversities in designing CSR programs or another development programs. This diversity awareness should be maintained through participatory communication activities in order to create sustainable social relations. In terms of sustainable environmental management, good social relations will be important prerequisite to rise community awareness and participation in practicing sustainable environmental management, as well as to enable multi-party collaborations in environmental conservation efforts with the incentives from CSR programs.

This study also suggests for the future research within the topic of Corporate Social Responsibility to focus on the local peoples' perspectives on the planned or already implemented CSR programmes. How the target groups perceive the meanings, usability, and impacts of the CSR programs should be the most important basis to plan and evaluate any CSR programs. 


\section{ACKNOWLEDGEMENT}

The author would like to thank to the Ministry of Education and Culture of the Republic of Indonesia (Kementerian Pendidikan dan Kebudayaan Republik Indonesia) for the Outstanding Community Scholarship (Biasiswa Masyarakat Berpretasi) that has supported the author's study and research as the basis of this article.

\section{BIODATA}

Miftah Faridl Widhagdha is a student at Extension and Development Communication Program, Graduate School of Gadjah Mada University, Indonesia. Email: arjuna.miftah@gmail.com

Hermin Indah Wahyuni is a senior lecturer at Communication Department, Gadjah Mada University and the Head of Centre for Southeast Asian Social Studies, Gadjah Mada University, Indonesia. Email: hermin_iw@ugm.ac.id

Muhammad Sulhan is a senior lecturer at Communication Department, Gadjah Mada University, Indonesia. Email: hansul@ugm.ac.id 


\section{REFERENCES}

Cantrill, J. (2015). Social science approaches to environment, media, and communication. In A. Hansen \& R. Cox (Eds.), The Routledge handbook of environment and communication (pp. 49-60). London \& New York: Routledge.

Coleman, J. S. (1988). Social capital in the creation of human capital. American Journal of Sociology, 94, S95-S120. Retrieved from www.jstor.org/stable/2780243

Cortado, F. J., \& Chalmeta, R. (2016). Use of social networks as a CSR communication tool. Cogent Business and Management, 3(1), 1-19. doi: $10.1080 / 23311975.2016 .1187783$

Edelman. (2009). Trust: 2009 Edelman Trust Barometer. Retrieved from https://www.edelman.com/sites/g/files/aatuss191/files/2018-10/2009-TrustBarometer-Global-Deck.pdf

Goodwin, N. R. (2003). Five kinds of capital: Useful concepts for sustainable development (Working Paper No. 03-07). Medford: Global Development and Environment Institute, Tufts University.

Grootaert, C., Narayan, D., Jones, V. N., \& Woolcock, M. (2004). Measuring social capital: An integrated questionnaire (World Bank Working Paper No. 18). Washington: The World Bank.

Healy, K., Haynes, M., \& Hampshire, A. (2007). Gender, social capital and location: Understanding the interactions. International Journal of Social Welfare, 16(2), 110118. doi: 10.1111/j.1468-2397.2006.00471

Jahdi, K., \& Acikdilli, G. (2009). Marketing communications and corporate social responsibility: marriage of convenience or shotgun wedding?. Journal of Business Ethics, 88, 103-113.

McCharty, J., Steenbergen, D., Warren, C., Acciaioli, G., Baker, G., Lucas, A., \& Rambe, V. (2017). Community driven development and structural disadvantage: Interrogating the social turn in development programming in Indonesia. The Journal of Development Studies, 53(12).

Miles, M. B., \& Huberman, A. M. (1994). Qualitative data analysis: An expanded sourcebook (2nd ed.). Thousand Oaks: Sage Publications.

Neuman, W. L. (2014). Social research methods: Qualitative and quantitative approaches (7th ed.). Pearson.

Putnam, R. (1993). The prosperous community: Social capital and public life. In E. Ostrom \& T. Ahn (Eds.), Foundation of social capital (pp. 35-42). Massachusetts: Edward Elgas Publishing Limited.

Widhagdha, M. F., Wahyuni, H. I., \& Sulhan, M. (2019). Relasi sosial dalam praktik kebijakan CSR. The Journal of Society and Media, 3(1), 105-123. doi: 10.26740/jsm.v3n1.p105125

Woolcock, M. (2001). The place of social capital in understanding social and economic outcomes. Canadian Journal of Policy Research, 2(1), 1-17.

Woolcock, M., \& Narayan, D. (2000). Social capital: Implications for development theory, research and policy. The World Bank Research Observer, 15(2), 225-249. doi: $10.1093 / \mathrm{wbro} / 15.2 .225$ 